\section{Research in Cutlery and Stainless Steel}

Is moving that the Cutlery and Stainless Steel Flatware Industry (Seiontifie Research Levy) Order, 1962, bo approved in the House of Commons on November 22, the Parliamentary Secretary to the Board of Trade, Mr. D. Price, said that the primary purpose of the Order was to increase the industry's contribution from $£ 9,000$ a year to just on $£ 14,000$. with a concomitant increase in the grant from the Department of Scientific and Industrial Research from $£ 6,000$ to $£ 9,000$. 'These resources would be used for research and dovelopment projects, a technical inquiry service and the dissemination of sciontific and technical information. The main research effort would be devoted to increasing the degree of mechanization in the industry, in which labour represented 50-60 per cont of manufacturing costs, and to reducing the number of manufacturing operations. That programme included resoarch on knife and scissor grinding, on multiple polishing, on abrasive operations and on the metallurgy of the edges of knives and scissors. Only firms with a turnover of $£ 10,000$ or more would be called on for an increased contribution, and exemption of the first $£ 3,000$ of turnover would reduce the number of firms liable for the lovy from 280 to 190. The Cutlery Roseareh Council had boon reconstituted, at the request of the Department of Scientific and Industrial Research, as an incorporated body under the title of the Cutlery and Allied Trades Research Association. The annual production of the industry, as defined for the purposes of the Order, was about $\$ 10$ million and it was exporting about $£ 3.5$ million a year.

\section{University of Delhl : Physiology of Reproduction}

THE Ford Foundation has made a grant of 195,000 dollars to the Dopartment of Zoology, University of Delhi, for expanding the facilities for research and training in the field of physiology of reproduction over a five-year period. Dr. M. R. N. Prasad and Dr. B. R. Soshachar will be the chief investigators in charge of the programme. As part of the activity envisaged in the Ford Foundation grant, the Department of Zoology has organized a training programme consisting of a series of sixteen seminars on physiology of reproduction in collaboration with Dr. Sheldon J. Segal, consultant to the Ford Foundation on reproductivo biology. The seminars are given by scientists from India and the United States. The seminar series, which was inaugurated by Dr. C. D. Deshmukh, vice-chancellor, University of Delhi, on October 22, will continuo until February 25, 1963.

\section{Scientific Research in France}

Increasing expenditure on research in France reflects a growing interest in science. Government assistance on a generous scale is extonded to scientific bodies from a spocial Scientific and Development Fund and, in the field of private enterprise, progressive firms co-operate in setting up research centros. Efforts are also being made to strongthen the ties between the universities and industry. A high. powered Inter-Ministerial Cornmittee on Scientific and Technical Research, under tho chairmanship of the Premier, was established in 1958 to advise the Governmont on the best ways of developing scientifio research, implementing scientifie equipment programmes and distributing proposed State expenditure on research among the various Government depart. ments. To advise the Committee there is a con- sultative body of twolve persons (known as the 'Committee of Wise Men') chosen by the Premier. The Centre National de la Recherche Scientifique acts as a co-ordinating body and is available to help all scientists, whatever their speciality and whatever the organization-State or private-for which they work. This body itself administers forty groups of laboratories or research institutes, including low-temperature research at Bellevue, astrophysics at HauteProvence, atomic synthesis at Ivry, macromolecular physics at Strasbourg, and solar energy utilization at Montlouis. At Beni-Abbès there is a Sahara Research Centre. In the field of medical research, the Pasteur Instituto -an independent, non-profitmaking body-has about 100 laboratories with 33 divisions covering a wide flold. About 18 Pasteur Institutes have been established in Africa, Asia and the West Indies. During the past twenty years, OSTROM (the overseas rosoarch organization) has set up many research centres in the tropics, the activities of which rango from geophysies and plant physiology to river hydrology and oceanography, The position of scientific research in France is outlinod in a publication recently issued by the SecrotaryGeneral of the French Government (France. Pp. 144. Paris : Secretariat Général du Gouvernement, Direction de la Documentation, 16, rue Lord-Byron, 1962).

\section{Minerva : a Review of Science, Learning and Policy}

BESIDES the text of Sir Eric Ashby's first Chancellor's Lecture to the Univorsity of the Witwatersrand, the first issue of Minerva, tho now quarterly review of science, loarning and policy, includos articles by Prof. W. Kornheuser on "Strains and Accommodations in Industrial Resoarch Organizations in the United States"; Dr. A. K. Singh on "The Impact of Foreign Study: the Indian Experience"; and Prof. M. Polanyi on "The Republic of Science: its Political and Economic Theory". There are also summarios of the reports of the Scientific Commission of Pakistan and of the report to the President of the United States on Government Con. tracting for Research and Development, and tho recommendations of the Science Council for the Development of Scientific Institutions in Western Germany (Minerva: a Review of Science, Loarning and Policy, Vol. I (Autumn 1962). Edited by Prof. Edward Shils. Pp. 1-144. (London: C.S.F. Publications, Ltd., 135 Oxford Street, 1962.) Publishod under the auspices of the Committee on Science and Freedom. Subseription-rate; 20s. or 5 dollars a year; single issues, 5s.) [See also p. 1241 of this issue of Nature.]

\section{Careers in Veterinary Science}

A RECENTLY published booklet in the sories on caroers issued by the Ministry of Labour provides a good general account of the prospects offored by a veterinary caroor (Central Youth Employment Exocutive. Choice of Careers, No. 111: The Veterinary Scientist. Pp. 32 (4 plates). London: H.M.S.O., 1962). The five chapters doal respoctively with educational and personal qualities required; training; scope and opportunitios; the work of the veterinary scientist; and work with the veterinary scientist. This last chapter concerns the work of the various types of auxiliaries employed privately, in Government services or elsewhore. These are experimontal officers, laboratory technicians, animal nurses, dressers, skillod animal attendants, otc. (Booklots 